6. Tsentralnyi derzhavnyi arkhiv hromadskykh ob'iednan Ukrainy (TsDAHO Ukrainy) [Central State Archives of Public Associations of Ukraine], f.1, op.20, spr.2691, 76 ark. [in Ukrainian].

7. TsDAHO Ukrainy [CDAGO of Ukraine], f.1, op.20, spr.6656. 39 ark. [in Ukrainian].

8. TsDAHO Ukrainy [CDAGO of Ukraine], f.1, op.20, spr.6876. 116 ark. [in Ukrainian].

9. TsDAHO Ukrainy [CDAGO of Ukraine], f.1, op.20, spr.7103. 69 ark. [in Ukrainian].

10. Shevchenku Tarasu pam'iatnyk [Taras Shevchenko monument]. Entsyklopediia. wek.kiev.ua. Retried from: http://wek.kiev.ua/uk/Шевченку_Тарасу_пам'ятник [in Ukrainian].

11. Shchekavytske kladovyshche [Shchekavichy Cemetery]. wikipedia.org. Wikipedia. Retried from: https://uk.m.wikipedia.org/wiki [in Ukrainian].

Одержано 18.04.2019.

УДК 340.136:94(477) «18/19»

\section{Грукач Вікторія,}

кандидат юридичних наук, доцент

кафедри загальної історії, правознавства i

методик навчання

Lesya612@ukr.net

https://orcid.org/0000-0003-4304-4831

Державний вищий навчальний заклад «Переяслав-Хмельницький державний педагогічний університет імені Григорія Сковороди»,

вул. Сухомлинського, 30, м. ПереяславХмельницький, Київська обл., Україна, 08401

\section{DOI https://doi.org/10.31470/2415-3567-2019. 46-85-92}

Hrukach Viktoria,

Candidate of Jurisprudence, Assistant Professor of General History, Science of Law, Teaching Methods Department

Lesya612@ukr.net

https://orcid.org/0000-0003-4304-4831

Pereiaslav-Khmelnytskyi Hryhorii Skovoroda State Pedagogical University,

30, Sukhomlynsky Str.,

Pereiaslav-Khmelnytskyi, Kyiv region, Ukraine, 08401

\section{Tkachenko Tetyana,}

Candidate of Historical Sciences, assistant professor of General History, Science of Law,

Teaching Methods Department tatiannatkachenko@gmail.com http://orcid.org/0000-0001-8534-6091

Researcher ID: V-8577-2018

Державний вищий навчальний «Переяслав-Хмельницький державний педагогічний університет імені Григорія Сковороди»,

вул. Сухомлинського, 30, м. ПереяславХмельницький, Київська обл., Україна, 08401
Researcher ID: V-8577-2018 Pedagogical University, 30, Sukhomlynsky Str., Pereiaslav-Khmelnytskyi, Kyiv region, Ukraine, 08401
Pereiaslav-Khmelnytskyi Hryhorii Skovoroda State

\title{
ПРАВОВІ ЗАСАДИ ФУНКЦІОНУВАННЯ КИЇВСЬКОГО ГЕНЕРАЛ-ГУБЕРНАТОРСТВА НА ПОЧАТКУ ХХ ст.
}

У статті здійснена спроба проаналізувати діяльність київського, волинського, подільського генерал-губернатор, яка мала сприяти подоланню польського впливу на Правобережжі України. На основі комплексного аналізу опублікованих та архівних джерел, історіографічних здобутків розглядються правові засади створення та подальшої еволюиії інституту генералгубернаторства у Правобережній Україні.

Метою статті є аналіз джерел та висвітлення законодавчих ініціатив, з якими виступали на початку XX cm. генерал-губернатори Південно-Західного краю для зменшення в иьому регіоні польського землеволодіння, що мало на той час важливе політичне значення. Констатовано, що 
Генерал-губернатор як головна посадова особа у генерал-губернаторстві представляв інтереси центральної влади, здійснював контроль за діяльністю всіх адміністративних органів на підвідомчій йому території. У цеентрі уваги генерал-губернаторів знаходились політичні проблеми, i саме генерал-губернатори визначали обсяг поширення у краї загальноросійських буржуазних реформ. Керівництво забезпечував за допомогою канцелярії, організаційно-штатна структура якої неодноразово змінювалася. У листопаді 1914 р. Київське генерал-губернаторство було ліквідоване.

Ключові слова: Київький генерал-губернатор, губернатор, губернське правління, дворянські зібрання, законодавчі інічіативи, Російська імперія, Правобережна Україна.

\section{LEGAL FRAMEWORK OF FEATURES KYIV GOVERNORS-GENERAL ERLY XX CENTURY}

Consider legislative initiatives General-governors who have to bridge the Polish influence on the Right Bank Ukraine. Based on comprehensive analysis of published and archival sources, historiography achievements the legal bases for the creation and further evolution of the Institute of General Governorship of Right Bank Ukraine are examined. It is reported that it was due to the introduction of a number of factors related to the special needs of the region, in particular, the continuation of the jurisdiction of Polish-Lithuanian legislation, availability of multi-ethnic composition of the population, lack of support for the new government from the local elite, dominant Catholic and Uniate churches, deficit of pro-government minded officials.

The activity of Kyiv governors-general, their legislative initiatives, relationships with governors and noble government agencies is analyzed. The reasons and circumstances of liquidation of Kyiv General Governorship in the early twentieth century are reported. The Governor-General, as the chief executive officer in the Governor-General, represented the interests of the central government, exercising control over the activities of all administrative bodies within his territory. Governors-general focuses on political issues, and it is governorsgeneral who determine the extent of the spread of bourgeois reform in the land of all-Russian bourgeois reform. The leadership was provided by the Office, the organizational structure of which was repeatedly changed. In November 1914, the Kiev Governor General was liquidated.

Key words: Kyiv governor-general, legislative initiatives, noble assemblies, Province Government, the governor, the Right-Bank Ukraine, the Russian Empire.

Важливу роль у функціонуванні держави відіграють центральні та місцеві адміністративні установи, через які держава реалізує свої функції контролю та управління соціально-економічними, політичними і культурними процесами на всій своїй території. Вивчення діяльності цих установ $\epsilon$ важливим для розуміння закономірностей та специфічних особливостей історичного процесу в окремих адміністративних одиницях.

Актуальність дослідження правового інституту генерал-губернаторства i його функціонування на Правобережжі України на початку XX ст. у сучасних умовах спричинена потребою розуміння складних та неоднозначних процесів у різних сферах життя українського суспільства, які були породжені ще раніше, у досліджуваний нами період, коли Російська імперія активно проводила в українських губерніях, зокрема у правобережних, політику зросійщення та інкорпорації. Вона спричинена також необхідністю реформування системи сучасного державного управління, проведення реформи з децентралізації влади та організації ефективної виконавчої влади в Україні на всіх рівнях.

Метою даної статті $€$ дослідження функціонування інституту генералгубернаторства у Правобережній Україні на початку XX ст., визначення його місця і ролі в системі державного управління Російської імперії.

Історіографічний дискурс розкриває стан сучасного наукового дослідження питання і констатує, що окремі питання інституту Київського генерал-губернатора знайшли своє 
відображення у працях М. Бармака, А.Градовського, В.Грукач, С. Дегтярьова, Л. Лисенка, С. Посохова, В.Шандри, О. Ярмиша $[5 ; 7 ; 8 ; 9 ; 10 ; 11 ; 13 ; 15]$ та ін.

XX ст. в Російській імперії, яка переживала економічну та політичну кризу, почалося масовими революційними виступами робітників, селян та студентів. Центральна і місцева влада виявилася не готовою для боротьби з ними. Надії на міністерство внутрішніх справ виявилися марними. Новий міністр внутрішніх справ В. Плеве, який, за словами начальника Київського охоронного відділення О. Спиридовича «На революційний рух, що відбувався в Росії у той час, продовжував дивитися очима $80-$ х років» [12, с. 110], поплатився за це життям: він був убитий есерами 15 липня 1904 р. Київські генералгубернатори не могли чекати допомоги центральної влади і могли розраховувати лише на власні сили. На перше місце в їх діяльності вийшла каральна функція. 17 березня 1903 р. генерал-губернатор М. Драгомиров видав постанову про заборону будь-яких зібрань.

3 початком революції 1905-1907 рр. царський уряд був змушений лібералізувати свою політику і йти на економічні, політичні й національні поступки. Імператор Микола II видав низку маніфестів: «Об учреждении Государственной думы» від 6 серпня 1905 р., «Об усовершенствовании государственного порядка» від 17 жовтня 1905 р., «Об улучшении благосостояния крестьянского населения» від 3 листопада 1905 р., в яких обіцяв недоторканість особи, свободи совісті, слова, мітингів, зібрань і союзів, скликання Державної думи, без схвалення якою не міг бути прийнятий жоден закон. Але не ці законодавчі акти взяли за основу своєї діяльності генерал-губернатори. Перш за все, вони керувалися «Положением о мерах к охранению государственного порядка и общественного спокойствия〉 від 14 серпня 1881 р., яке надавало їм надзвичайні повноваження.

Аналіз документів фонду Київського генерал-губернатора свідчить, що він активно використовував надані «Положенням» повноваження. За підрахунками О.Н. Ярмиша генерал-губернатор В. Сухомлинов з кінця 1905 до 1 березня 1907 р. затребував з органів прокуратури 171 слідчу справу; повернуто ж було для направлення у загальному порядку лише 63 справи. Інші 108 справ було передано до військових судів, або розглянуто в адміністративному порядку. Усього ж з листопада 1905 р. по листопад 1908 р. генералгубернатор направив у військово-окружний суд 218 справ, у яких обвинуваченими були цивільні особи [14, с. 61].

Коли ж для суду не вистачало доказів, генерал-губернатор вирішував справу в адміністративному порядку. У 1905-1907 рр. адміністративних покарань (висилки, тюремного ув'язнення, арешту і грошових штрафів) у Південно-Західному краї зазнали 1048 осіб, у 1908 р. - 567, у 1909 р. - 298 осіб [14, с. 59]. I хоч революція вже була придушена, уряд довго не наважувався припинити дію стану посиленої охорони. Царським указом від 11 серпня 1910 р. в частині повітів стан посиленої охорони було припинено, але там же зазначалось, що повноваження, передбачені ст. 15 і п. 1 ст. 16 (право видавати обов'язкові постанови і розглядати справи про їх порушення в адміністративному порядку) за генерал-губернатором залишаються.

Згадуваний нами Маніфест 17 жовтня 1905 p., інші законодавчі акти доби революційного часу, проголошуючи політичні права і свободи, сприяли активізації діяльності на Правобережжі України римо-католицької церкви, поширенню польської мови та польських освітніх закладів. Скасовувалися обмеження, що стосувалися польського землеволодіння і землекористування.

У квітні 1905 р. був прийнятий закон, який проголошував свободу віросповідання i давав певні свободи римо-католицьким священникам [14, с. 192]. Згідно нього було дозволено викладати польську мову та Закон Божий у державних школах Королівства, вживати польську мову в діловодстві, проголошувалася свобода віровизнання. Скасовувалися обмеження стосовно польського землеволодіння у литовських, білоруських та правобережних українських губерніях. Закон від 1 травня 1905 р. дозволяв особам польського походження орендувати землю на загальних, без обмежень у термінах, 
підставах в межах дев'яти західних губерній, а також купувати іiі і брати під заставу в осіб польського походження [14, с. 193]. Цим законом полякам також надавалось право в названих губерніях купувати 3 дозволу генерал-губернаторів нерухомість поза межами міст і містечок для ліквідації черезполосиці, а також обмінювати цю нерухомість на іншу.

Безумовно, що місцева адміністрація досить насторожено віднеслась до всіх цих законів. «Після оприлюднення закону 1 травня 1905 р., який дозволив полякам купувати землю у поляків, і у зв'язку з широким розвитком діяльності Селянського банку, - писав у своєму звіті подільський губернатор Ейлер, - польське землеволодіння почало знову збільшуватися в губернії на противагу російському; тим самим зовсім паралізована мета попереднього закону, яка мала державне значення, - поступове обрусіння Подільської губернії через перехід польських маєтків до російських рук і зменшення тим самим у губернії польського впливу. Поляки останнім часом відкрито заявляють, що не уступлять російському землеволодінню в Подільській губернії і метра землі і що Польща має відродитися в попередніх межах від моря Балтійського до Чорного» [3, арк. 12].

Далі подільський губернатор повідомляв, що російське землеволодіння в губернії за період з 1905 р. по 1909 рік зменшилось більш, ніж у 6 разів порівняно з польським, у той час як за названий період жоден польський маєток не перейшов до рук російських землевласників, і були випадки, коли поляки продавали маєтки дешевше, але особам польського походження. Тому повернення до заборони полякам купувати землю в Подільській губернії, на думку Ейлера, було єдиним і дуже бажаним засобом, на дієвість якого в справі обрусіння краю можна було сподіватись.

Гострим залишалося на Правобережній Україні питання початкової освіти, адже на іiі територію не поширювалась земська реформа і тут не було ані земських шкіл, ані земських лікарень. Була лише невелика кількість церковних шкіл. У зв'язку з цим, київський губернатор Ф. Трепов у звіті за 1898 р. писав, що в губернії «одна церковнопарафіяльна школа припадає на 3564 жителів губернії, і на 46 квадратних верст, одна ж школа відомства Міністерства народної освіти припадає на 15493 душі населення губернії» [1, арк. 10 зв.]. Варто відзначити що це були середні показники по губерніях. У деяких же повітах краю показник грамотності українського населення був значно нижчим і нерідко одна народна школа припадала на 120 і більше квадратних верст [1, арк. 17].

Зазначимо, що й на початку XX ст. стан народної освіти продовжував залишатись таким же критичним, як і в кінці ХIX ст. Відвідавши у 1909 р. 36 повітів ПівденноЗахідного краю, Ф. Трепов, який уже став київським генерал-губернатором, змушений був констатувати, що в краї до 60 \% дітей шкільного віку залишаються поза школою за відсутністю таких [3, арк. 10 зв.].

Для тих дітей, які навчалися у початкових школах, проблемою залишалася російська мова викладання, якої вони не розуміли. Питання про доцільність заборони українського слова виникло на засіданнях Комітету міністрів 28 і 31 грудня 1904 р. Для розгляду цього питання була створена комісія під головуванням академіка Ф. Корфа. Однак лише 3 виданням Маніфесту 17 жовтня і Тимчасових правил про пресу від 24 листопада 1905 р. антиукраїнські закони втратили свою силу. Було дозволено видавати газети, журнали і книжки українською мовою, створювати просвітницькі товариства.

В умовах наступу реакції, місцева влада вирішила ліквідувати ті прояви українства, що з'явилися в краї у період революційного піднесення. Наприкінці грудня 1909 р. київський губернатор О. Гірс надіслав київському генерал-губернатору Ф. Трепову конфіденційного листа відносно існування у Київській губернії українських і польських просвітницьких товариств. Охарактеризувавши діяльність «Польського союзу», «Київського польського жіночого гуртка», «Київського гуртка польських літераторів та журналістів», губернатор зазначав, що вони переслідують цілі, які «...ідуть проти історичних завдань російської державної політики у Південно-Західному краї...». Він був схвильований тим, що: «Значно небезпечнішою $є$ програма «українських» товариств, які виникали протягом останніх трьох років і ставлять за мету пропаганду через місцевих 
жителів так званої «української мови». Товариства ці намагаються витіснити російську мову із побутового вжитку та народних аудиторій, спектаклів і концертів; наступним етапом «українського руху», передбачається завоювання школи» [3, арк. 3].

12 лютого 1910 р. київський генерал-губернатор Ф. Трепов звернувся до міністерства внутрішніх справ 3 листом про закриття «Польського союзу», «Київського жіночого польського гуртка», «Київського гуртка польських літераторів і журналістів», Товариства «Просвіта», «Українського наукового товариства у Києві», «Українського товариства сприяння науці, літературі і мистецтву у м.Києві» та «Київського українського громадського зібрання», мотивуючи це тим, що «діяльність цих товариств направлена на посилення національної «обособленности и розни» [3, арк. 11].

Заступник міністра внутрішніх справ С. Крижанівський відповів відмовою. Він рекомендував, аби губернські присутствія переглянули свої рішення про реєстрацію названих товариств. Київський генерал-губернатор звернувся за пропозиціями до підлеглих йому губернаторів. На початку лютого 1910 р. міністерство внутрішніх справ видало циркуляр, в якому губернаторам наказувалося не дозволяти заснування «инородческих» товариств, зокрема українських та єврейських, незалежно від їх цілей, а також переглянути всі видані раніш дозволи і вжити відповідних заходів.

8 квітня 1910 р. під головуванням київського губернатора О. Гірса відбулось засідання губернського присутствія у справах про товариства, яке прийняло наступне рішення: «Вбачаючи як в цілях, поставлених перед товариством «Просвіта» його статутом, так i у видавничій діяльності товариства впродовж чотирьох років його існування загрозу громадському спокою і безпеці», - присутствіє постановило: «Товариство під назвою «Просвіта» у Києві закрити назавжди, про що оголосити правлінню товариства через поліцмейстера, якому доручити зупинити всяку діяльність товариства [3, арк. 12]. Крім київської «Просвіти» на Правобережжі були закриті просвітницькі організації у Кам'янці-Подільському та Житомирі.

Основною своєю опорою центральна i місцева влада вважала поліцію i жандармерію. Реформа поліції в Правобережній Україні ставала потребою часу. Оскільки нижчі чини поліції отримували мізерну платню, нижчу ніж кваліфікований робітник, то вони брали хабарі. Громадськість краю була переконана, що поліція відзначається низьким професійним рівнем, оскільки поповнювалась вона малоосвіченими людьми 3 низькими моральними якостями. Відділення поліцейських функцій від основних їх обов'язків у діяльності волосних старшин і сільських старост та введення найманих посад у поліції, які пропонував київський генерал-губернатор М. Драгомиров, були покладені в основу реформи поліції, яку розпочав уряд на початку XX ст.

Реформа поліції велася у трьох напрямках: збільшенням кількості поліцейських, підвищення їх грошового утримання, введенням фабрично-заводської поліції, яка фінансувалася частково за рахунок приватних підприємців. Так, за даними проф. О. Ярмиша, у 1902 р. кількість поліції у Києві було збільшено з 583 до 666 осіб [14, с. 72]. Загальна кількість поліції в імперії зросла з 76 тис. у 1904 р. до 136 тис. у 1907 р. Кількість поліцейських у кожній губернії становила близько 2 тис. Одночасно майже на 25 \% зросла їхня зарплата. Ще в кінці XIX ст. була узаконена фабрично-заводська поліція. Витрати казни на утримання поліції зросли з 27,2 до 50,7 млн. руб. Але результати не виправдали затрат [14, с. 73]. Служба в поліції залишалася непрестижною і низькооплачуваною: поліцейський отримував менше ніж кваліфікований робітник, а становий пристав - менше службовця в приватній фірмі. Тому питання реформи державної поліції залишалось відкритим.

Пропозиції генерал-губернатора М.І. Драгомирова були враховані при поширенні у 1904 р. реформи земського самоврядування на Київську, Подільську і Волинську губернії. Враховуючи значний вплив поляків на органи місцевого самоврядування і намагаючись зменшити його, правління місцевими господарськими справами передавалися не 
виборним земським установам, а в губернські комітети у справах земського господарства, до складу яких входили чиновники місцевих установ та повітові гласні.

У той час до питань, що потребували негайного вирішення, генерал-губернатор відніс становище чиншовиків, пропонуючи переселити їх на нові, вільні землі. При розгляді питання про іммігрантів він підтримав курс свого попередника О.П. Ігнатьєва на заборону їхнього поселення в Південно-Західному краї. При з'ясуванні урядом його позиції щодо переселення сюди поляків з Царства Польського, M.I. Драгомиров вважав, що це питання слід вирішувати окремо у кожному конкретному випадку. Генералгубернатор підтримав проведення у Києві у 1900 р. наради лікарських інспекторів Південно-Західного краю та ХІ археологічного з’їзду 1899 р. [11, с. 118].

Набуття чинності законів, прийнятих у 1904-1906 рр., які позбавляли генералгубернаторів низки повноважень, пов'язаних з проведенням урядової обмежувальної земельної, релігійної та мовної політики, дозволило Державній думі 1910 р. ставити питання про ліквідацію посади київського, подільського i волинського генералгубернатора. Цьому сприяло і те, що тодішній генерал-губернатор В.О. Сухомлинов (1905-1908 рр.), будучи військовим за покликанням і одночасно займаючи посаду командувача Київським військовим округом, мало приділяв уваги цивільним справам. Однак тоді ця пропозиція не дістала схвалення і Київське генерал-губернаторство проіснувало ще чотири роки.

Останнім київським генерал-губернатором був Ф.Ф. Трепов-молодший, призначений на цю посаду Миколою II 18 грудня 1908 р. [8, с. 128]. Він добре знав цей регіон, оскільки протягом десяти років служив військовим чиновником з особливих доручень при генералгубернаторах О. Р. Дрентельні (1881-1888рр.) та О. П. Ігнатьєві (1889-1897 рр.), волинським (1894-1896 рр.), а в 1896-1903 рр. - київським цивільним губернатором [8, с. 129]. На його переконання, владі слід було зосереджуватися на проведенні земської реформи, з наданням їй змісту охорони ідеї російської народності й державності. У 1911 р. уряд наважився впровадити в Південно-Західному краї земства, але нагляд за проведенням цієї реформи цілком покладався на генерал-губернатора, який повинен був оперативно, щотижня телеграфом інформувати центральну владу про хід роботи в цьому напрямку: укладення списків виборців, висунення кандидатів у земські гласні, відкриття нових земських управ.

Ф.Ф. Трепов, як і його попередники, звертав увагу імператора та уряду на посилення католицького впливу, викликаного законодавчим актом від 17 квітня 1905 р. про свободу віросповідання та вказував на поширення іноземної колонізації в краї (чеської та німецької). Зважаючи, що М.I. Драгомиров 1901 р. припинив видачу колоністам свідоцтв на право купівлі землі, а В. О. Сухомлинов 1907 р. надіслав клопотання про поширення на весь Південно-Західний край закону від 14 березня 1895 р. про право купівлі землі іноземцям, які прийняли російське підданство лише у Волинській губернії, то необхідно було унормувати ці акти.

Підтримуючи пропозиції М.I. Драгомирова Ф.Ф. Трепов підготував проект, за яким уряд мав послідовно припиняти колонізацію «іноземцями-католиками» не лише на території Волинської губернії, а й не дозволяти їм селитися у всьому Південно-Західному краї. Генерал-губернатор пропонував повернутися до обмеження оренди землі євреями, прирівняти умови викупів земельних ділянок чиншовиків до викупу землі селянами. Однак проблеми, які він піднімав, уже мало хвилювали верховну владу, перед якою стояли питання, що були пов'язані з початком Першої світової війни.

Рішення про ліквідацію Київського генерал-губернаторства, підготовлене Радою міністрів і затверджене Миколою II 10 жовтня 1914 р. Причини необхідності ліквідації посади генерал-губернатора Південно-Західного краю були викладені в «Докладе по законодательному предположению об упразднении должностей киевского, подольского и волынского генерал-губернатора и степного генерал-губернатора», де зазначалось, що доцільність створення Київського генерал-губернаторства у свій час пояснювалося 
передусім тим, що в першій половині XIX ст. регіональні особливості Правобережжя були маловідомими для вищих установ, а тому довелося майже все управління краєм зосереджувати в руках однієї особи $[4$, с. 2$]$.

На початку XX ст. посада генерал-губернатора стала зайвою, оскільки генералгубернаторство виконало свої надзвичайні завдання. Губернії, що його складали «міцно зблизились 3 корінними місцевостями імперії» і переводяться на губернську форму управління. Захоплення російською армією в ході війни нових західних територій, знімало 3 Правобережної України іiі прикордонне становище. Питання загальнодержавного значення, що їх раніше з'ясовував генерал-губернатор, передавалися на відповідальність міністрів, місцевого - до відповідних губернаторів [8, с. 130].

Таким чином, Генерал-губернатор як головна посадова особа у генералгубернаторстві представляв інтереси центральної влади, здійснював контроль за діяльністю всіх адміністративних органів на підвідомчій йому території. У центрі уваги генерал-губернаторів знаходились політичні проблеми, i саме генерал-губернатори визначали обсяг поширення у краї загальноросійських буржуазних реформ. Керівництво забезпечував за допомогою канцелярії, організаційно-штатна структура якої неодноразово змінювалася. У листопаді 1914 р. Київське генерал-губернаторство було ліквідоване.

\section{ДЖЕРЕЛА ТА ЛІТЕРАТУРИ}

1. Копии всеподданейших отчетов губернаторов Юго-Западного края. 31 мая 1896 - 12 февраля 1904 гг. Центральний державний історичний архів України у м. Києві (ЦДІАК України). Ф. 442. (Канцелярія київського, подільського і волинського генералгубернатора). Оп. 626. Спр. 20. 120 арк.

2. Дело о реформе полиции. ЦДІАК України. Ф. 442. Оп. 630. Спр. 354.410 арк.

3. Дело со статистическими обзорами по Киевской, Подольской и Волынской губерниям (1909 и 1910 гг.). ЦДІАК України. Ф. 442. Оп. 641. Спр. 704.23 арк.

4. Доклад по законодательному предположению об упразднении должностей киевского, подольского и волынского генерал-губернатора и степного генералгубернатора. Санкт-Петербург, 1911. 24 с.

5. Бармак М.В. Формування владних інституцій Російської імперії на Правобережній Україні (кін. XVIII - пер.пол. XIX ст.). Тернопіль, 2007. 512 с.

6. Блинов И. Губернаторы: Историко-юридический очерк. Санкт-Петербург: Типолитография К.Л. Пентковского, 1905. 366 с.

7. Градовский А.Д. Исторический очерк учреждения генерал-губернаторства в России: Собр. соч. Санкт-Петербург: Типография М.М. Стасюлевича, 1899. Т. 1. С. 299 - 338.

8. Грукач В.О., Ткаченко О.В. Інститут генерал-губернаторства у Правобережній Україні : правові засади та особливості функціонування (1832-1914). ПереяславХмельницький: ФОП Домбровська Я.М., 2017. 203 с.

9. Дегтярьов С.I. Цивільне чиновництво україни у кінці ХУІІІ - першій половині XIX ст. Суми: ТОВ «Друкарський дім «Папірус», 2014. 472 с.

10. Лисенко Л.М. Губернаторы и генерал-губернаторы Российской империи (XV начало XX века). Изд. 2-е, испр. и доп. Москва: Изд-во МПГУ, 2001. 354 с.

11. Посохов С.И., Ярмыш А.Н. Губернаторы и генерал-губернаторы. 2-е изд., исп. и доп. Харьков: Акта, 1996. 206 с.

12. Спиридович А.И. Записки жандарма. Москва, 1991. 263 с.

13. Шандра В.С. Київське генерал-губернаторство (1832-1914): Історія створення та діяльності, архівний комплекс та його інформативний потенціал. Київ: Укр. держ. НДІ арх. справи та документознавства, 1999. 144 с.

14. Ярмиш О.Н. Каральний апарат самодержавства в Україні в кінці XIX - на початку XX ст. Харків: Консум, 2001. 288 с. 


\section{REFERENCES}

1. Kopii vsepoddaneyshih otchetov gubernatorov Yugo-Zapadnogo kraya. 31 maya 1896 12 fevralya $1904 \mathrm{gg}$. [Copies most arrogant governor's reports of the Southwestern Territory. 31 may 1896 - 12 february 1904]. Tsentralnyi derzhavnyi istorychnyi arkhiv Ukrainy u m. Kyievi (TsDIAK Ukrainy) - Central State Historical Archives of Ukraine in Kyiv (CSHA of Ukraine). F. 442. (Kantseliariia kyivskoho, podilskoho i volynskoho heneral-hubernatora). Op. 626. Spr. 20. 120 ark. [in Ukrainian].

2. Delo o reforme politsii [Police reform case]. TsDIAK Ukrainy - CSHA of Ukraine. F. 442. Op. 630. Spr. 354. 410 ark. [in Ukrainian].

3. Delo so statisticheskimi obzorami po Kievskoy, Podolskoy i Volyinskoy guberniyam (1909 i 1910 gg.) [The case with statistical surveys in the Kiev, Podolsk and Volyn provinces (1909 and 1910]. TsDIAK Ukrainy - CSHA of Ukraine. F. 442. Op. 641. Spr. 704. 23 ark. [in Ukrainian].

4. (1911). Doklad po zakonodatelnomu predpolozheniyu ob uprazdnenii dolzhnostey kievskogo, podolskogo $i$ volyinskogo general-gubernatora $i$ stepnogo general-gubernatora. Sankt-Peterburg [Report on the legislative assumption on the abolition of the posts of Kiev, Podolsky and Volyn governor-general and steppe governor-general. St. Petersburg] [in Russian].

5. Barmak, M.V. (2007). Formuvannia vladnykh instytutsii Rosiiskoi imperii na Pravoberezhnii Ukraini (kin. XVIII - per.pol. XIX st.) [Formation of Power Institutions of the Russian Empire on Right-Bank Ukraine (End of XVIII - BC of XIX Century)]. Ternopil [in Ukrainian].

6. Blinov, I. (1905). Gubernatoryi: Istoriko-yuridicheskiy ocherk [Governors: Historical and Legal Essay]. Sankt-Peterburg: Tipolitografiya K.L. Pentkovskogo [in Russian].

7. Gradovskiy, A.D. (1899). Istoricheskiy ocherk uchrezhdeniya general-gubernatorstva $v$ Rossii [The historical outline of the establishment of the Governor General in Russia]. (Vol.1.) Sankt-Peterburg: Tipografiya M. M. Stasyulevicha [in Russian].

8. Hrukach, V.O., \& Tkachenko, O.V. (2017). Instytut heneral-hubernatorstva $u$ Pravoberezhnii Ukraini: pravovi zasady ta osoblyvosti funktsionuvannia (1832-1914). [Governor-General's Institute in Right-Bank Ukraine: Legal Foundations and Functioning Features (1832-1914)]. Pereiaslav-Khmelnytskyi: FOP Dombrovska Ya.M. [in Ukrainian].

9. Dehtiarov, S.I. (2014). Tsyvilne chynovnytstvo ukrainy u kintsi XVIII - pershii polovyni XIX st. [Civil bureaucracy of Ukraine at the end of the 18th - the first half of the 19th century]. Sumy: TOV «Drukarskyi dim «Papirus» [in Ukrainian].

10. Lisenko, L.M. Gubernatoryi i general-gubernatoryi Rossiyskoy imperii (XV-nachalo $X X$ veka) [Governors and governors-general of the Russian Empire (XV - beginning of the $X X$ century)]. Izd. 2-e, ispr. i dop. Moscow: Izd-vo MPGU [in Russian].

11. Posohov, S.I., \& Yarmyish, A.N. (1996). Gubernatoryi $i$ general-gubernatoryi [Governors and Governors General]. 2-e izd., isp. i dop. Harkov: Akta [in Ukrainian].

12. Spiridovich, A.I. (1991). Zapiski zhandarma [Gendarme notes]. Moskow [in Russian].

13. Shandra, V.S. Kyivske heneral-hubernatorstvo (1832-1914): Istoriia stvorennia ta diialnosti, arkhivnyi kompleks ta yoho informatyvnyi potentsial [Governor General of Kiev (1832-1914): History of creation and activity, archival complex and its informative potential]. Kyiv: Ukr. derzh. NDI arkh. spravy ta dokumentoznavstva [in Ukrainian].

14. Yarmysh, O.N. (2001). Karalnyi aparat samoderzhavstva v Ukraini v kintsi XIX - na pochatku XX st. [The punitive apparatus of autocracy in Ukraine in the late nineteenth and early twentieth centuries.]. Kharkiv: Konsum, 2001 [in Ukrainian].

Одержано 28.01.2019. 